\title{
Empowering Women in the Arab World between the Requirements of Law and the Requirements of Reality
}

\section{Dr. Mohammad Hadie Al Najdawi}

Assistant Professor, General Education, City University College of Ajman, United Arab Emirates

\section{M.najdawi@cuca.ae}

\begin{abstract}
:
Women and their issues have become the focus of most researchers in the social, legal, political and economic fields, in addition to the official and unofficial institutions of the country. Being a major and influential actor in the lives of societies due to the main roles it plays on the one hand, and on the other hand, given that the issue of women and their empowerment is not a national issue, but rather has become an issue of international dimensions resulting from global interest in it; In addition to adopting her cause in all international forums, conventions and treaties concerned with human rights, not to mention the international conferences supporting the principle of empowering women, given that eliminating all forms of discrimination against women is not only a basic human right, but also a factor critical to accelerating the achievement of sustainable development, It has been proven that empowering women has a multiplier effect, especially by driving economic growth and development in society. Hence, this study sheds light on the concept of women's empowerment and its importance in order to create comprehensive development, in which the latter is based on the principle of providing opportunities and equality based on the legal requirements that guarantee this, and on the basis of what is stated in international charters and treaties related to this matter, as this study attempts Monitoring the efforts undertaken by the Arab countries to recognize and enforce the human rights of women, and to reveal the problems that hinder the achievement of the empowerment process in the Arab world.
\end{abstract}

Keywords: Empowerment, Women, the Arab world, Legal requirements, International conventions, Obstacles to empowerment. 


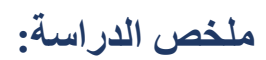

أضحت المر أة وقضاياها محل اهتمام جلّ الباحثين في الحقل الاجتماعي و القانوني و السياسي و الاقتصادي، إلى جانب اهنمام المؤسسات الرسمية للدولة و غير الرسمية فيها؛ لكونها تمثل فاعلاً رئيسياً ومؤثر اً في حياة المجتمعات نظر أ للأدوار الرئيسية ولئية

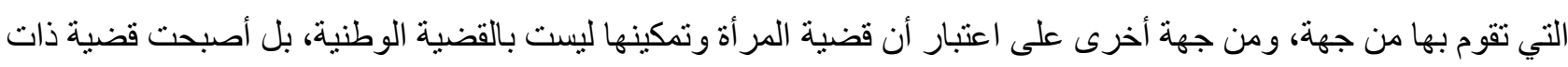
أبعاد دولية ناتجة عن الاهتمام العالمي بها؛ إلى جانب تبني قضيتها في كافة المحافل والاتفاقيات و المعاهدات الدولية التي تعنى اعنى بشأن حقوق الإنسان، ناهيك عن المؤتمر ات الدولية الداعمة لمبدأ تمكين المر أة، وذلك بالنظر إلى أن القضاء على التهاء كافة أثكال التمييز ضد المر أة لا يمثل حقاً أساسياً من حقوق الإنسان فحسب، بل هون الئن أيضاً عامل حاسم يعجل من تحقيق التتمية المستدامة، حيث ثبت أن تمكين المر أة له أثر مضاعف، خاصة بالدفع نحو النمو الاقتصادي و التتمية في المجتمع. من ثم تأتي هذه الدراسة

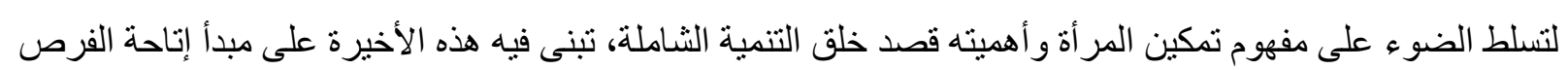
و المساو اة انطلاقاً من المقتضيات القانونية التي تكفل ذلك، و انطلاقا مما جاءت به المو اثيق و المعاهدات الدولية المتعلقة بهذا الثأن، كما تحاول هذه الدر اسة رصد الجهود التي قامت وتقوم بها الدول العربية لإقرار وتنزيل الحقوق الإنسانية للمر أة، و الكثف عن الإشكالات التي تعيق تحقيق عملية التمكين في الوطن العربي. الكلمات المفتاحية: تمكين، المر أة، الوطن العربي، المقتضيات القانونية، المو اثيق الدولية، معيقات التمكين.

\section{Introduction:}

Full respect for human rights, with their different generations and their various ramifications, is among the strong and indicative indicators of the level of the flow of modernity, the degree of democracy sovereignty and the achievement of development. Accordingly, the dialectical relationship between democracy and development is getting stronger when it comes to women's rights and the extent of their presence in managing public affairs. The explanation for this is due to two considerations: the first is related to the reality of neglect, marginalization, and long-term exclusion that befell women, not only from a human rights perspective, but from an empowerment perspective as well. The second consideration is linked to the extent of commitment to the democratic option and to achieving development, not by the international community, which includes international organizations only, but by countries through their legislative and legal systems, strategies and internal public policies. 
Statistically, women constitute more than half of the population in the Arab world, but the issue of empowering them did not begin to emerge until the late nineties.

Where the issue of involving women in the development process was a major requirement, and with the increase in global awareness, women's issues became among the international and national priorities, especially after it was proven to everyone that putting women on the sidelines results in disruption and obstruction of development policies and development.

This made the issue of women's empowerment one of the central topics and issues in the eighties of the last century, and today it remains a priority for study and research, as the World Bank considered it one of the basic elements in the development process and the fight against poverty. It was also considered as one of the development goals due to its connection to achieving the goal of social justice and its link also to other goals such as fighting poverty, where full access to resources is a strong indicator of women's empowerment, and achieving this indicator undoubtedly leads to the achievement of sustainable development goals (carrying out reforms that grant women equal rights to economic resources The right to own and dispose of land and other property, financial services, inheritance and natural resources in accordance with national laws.

Eliminating all discrimination against women and girls is not only a fundamental human right, but also a critical factor in accelerating sustainable development. It has been proven that empowering women has a multiplier effect, especially by pushing towards economic growth and development in all fields.

However, women in the Arab region face significant barriers to entering the labor market and are at much greater risk of unemployment compared to men. Although the unemployment rate among women has been slowly declining over the past fifteen years, the unemployment rate among women is more than double that of men in the region. Sexual violence and exploitation, the unequal burden of domestic and unpaid care work, and discrimination in public office remain huge barriers to achieving gender equality. 


\subsection{Study problem:}

The challenges that women face are rooted in the social, political, economic and cultural structure in the Arab world, which ultimately leads to tightening the siege around them and limiting the opportunities available to them compared to men. It prevents the achievement of gender equality and the enjoyment of their human rights, and the opportunity to empower them is reduced, which affects the general societal environment. In this regard, the problem of the study is the following:

- To what extent have legislative and legal requirements empowered Arab women with their human rights?

\subsection{Study questions:}

Based on the problem posed, several sub-questions appear, which can be summarized as follows:

1. What is the theoretical concept of empowerment, and how did it move from its general dimension to a concept that translates support for women's access to their rights?

2. What are the paths taken by the international community to recognize women's rights and ensure their empowerment?

3. What are the legal requirements adopted to approve the empowerment of women in the Arab countries?

4. Can we say that the legislative system and the national strategies adopted by the Arab countries have been able to empower Arab women?

\subsection{Research Importance}

The importance of this research can be determined at several levels:

1. Revealing the general conceptual framework of the concept of empowerment and the empowerment of women in particular, its indicators and dimensions. 
2. Learn about the international efforts exerted to establish effective empowerment of women at the international and national levels.

3. Revealing the path of some Arab experiences in approving women's rights and downloading the concept of empowerment constitutionally, legally and through national strategies and plans.

4. Monitoring the problems and obstacles that prevent the actual empowerment of women.

\subsection{Research Aims:}

This research aims to achieve:

1. Knowing the theoretical and conceptual framework of the concept of empowerment.

2. Uncovering the path crystallization of the concept of empowerment and the international orientation for its approval as one of the sustainable development goals.

3. Learn about some Arab experiences to empower women and guarantee their human rights

4. Identifying the problems that hinder the realization of the human rights of women in the Arab world.

\subsection{The method adopted in the research:}

Based on the research problem and the related sub-questions, the analytical approach was relied upon, by analyzing and dismantling the basic elements of the research topic and its problematic, and working to study these elements in depth, which enabled us to derive judgments about the status of women's empowerment in the Arab world, and to reveal The outcomes of the efforts made by Arab countries to achieve empowerment.

\subsection{Search Plan:}

The first topic: Empowering women from the theoretical concept to international and national procedures

The first requirement: the conceptual framework for empowerment; Dimensions and indicators.

The first paragraph: What is empowerment from the public to the particular? 
The second paragraph: Dimensions and indicators of women's empowerment

The second requirement: tracks of international and Arab efforts to empower women

Paragraph one: International efforts to endorse the principle of women's empowerment

The second paragraph: Arab countries and the problem of downloading the principle of empowering women

The second topic: What are the legal and constitutional dimensions for empowering women in the Arab world?

The first requirement: the constitutional and legal references, i.e. a role for empowering women in the Arab world

The first paragraph: the constitutional and legal foundations that embody the principle of women's empowerment

The second paragraph: Examples of Arab strategies to implement the principle of women's empowerment

The second requirement: the constraints of achieving women's empowerment in the Arab world

The first paragraph: the limitations of public policies directed at empowering women

The second paragraph: the dominance of inequality values in the Arab sociocultural dimension

The First topic: empowering women from the theoretical concept to international and national procedures

Taking real and effective measures on the path to empowering women is an important entry point to address major political, social and economic problems and dilemmas. The empowerment of women refers to all measures, procedures and legislation that support the integration of women into society, develop their competencies and enhance their participation in various fields and fields, 
Making them aware of their capabilities in a way that leads to their integration into society and effectively contribute to its development [1].

The inclusion of women and ensuring their participation in the development process remains, not as a recipient or consumer, but as a basic active member, which is related to the extent to which they are enabled to achieve equality between them and men. This topic will address the conceptual framework of empowerment with its dimensions and indicators, as a process that allows building a balance between everyone and ensuring everyone's contribution to development (the first requirement), It will also discuss the efforts made at the international level as well as at the level of the Arab world to empower women (the second requirement).

\section{The First requirement: the conceptual framework for empowerment; Dimensions and indicators}

The interest in the principle of empowerment and the roles it can play in favor of the less fortunate and the most vulnerable groups, has moved it from its public domain to the field of approaches concerned with the advancement of women. Consequently, the principle of empowering women as a concept and strategies has become one of the most prominent principles that are relied upon to achieve societal balance and equity for women. What is the nature of empowerment? What are the dimensions and indicators of women's empowerment?

\section{The first paragraph: What is empowerment from the public to the particular?}

Empowerment is defined as "the process of transforming existing power relations and acquiring greater control over sources of power. It is the process of strengthening the capabilities of individuals or groups to make choices and transforming those choices into actions and desired results.”

The concept of empowerment as a general concept refers to those strategies that increase the capabilities of individuals to deal with obstacles related to problems, develop their standard role, and increase their abilities to make societal decisions and decisions related to their private lives, and thus refers to strategies by which individuals and groups can be helped alike. From controlling her circumstances and achieving her goals, where she is able to work to help herself and others and increase her standard of living [2]. 
Moving from the general concept of empowerment to its concept specific to women, we find that this concept associated with Women's Empowerment emerged in the eighties of the last century, as a concept that refers to women's ability to use available resources and make strategic decisions that affect their lives, enabling them to determine their destiny and achieve their interests [3]. Consequently, many definitions of the concept of women's empowerment have been adopted, all of which embody the extent to which women can contribute to making decisions and influence the course of matters that are important to them. Among these definitions are those who consider empowerment “support for women's ability and ability to influence the social institutions that affect their lives" and here came the definition of Naila Empowerment is significant in “increasing women's ability to make crucial decisions in their lives, which requires changing the entire social system, that is, bringing about a radical change in it, and reformulating it anew so as to divide roles, responsibilities and rights on a more balanced and equal basis" [4].

On the other hand, the empowerment of women has been linked to the process through which women become individually and collectively aware of the way in which signs of strength affect their lives, gaining self-confidence and the ability to address inequality between them and men, which is focused on addressing discrimination against women through programs and strategies It aims to increase their capabilities and opportunities, and work to strengthen their capabilities with regard to their human rights, as well as to give priority to initiatives that seek to create conditions that make women responsible for their own development and empowerment.

If this is the case, then the process of empowerment here is based on the sufficient capacity for change in development initiatives, and thus highlights the ways in which women can create on their own a new space for work and movement [5], which is thus a dynamic process aimed at eliminating all forms of discrimination and inequality, Reaching the goal of this process requires the removal of all legal, social, political and economic obstacles, and other stereotypical behaviors that place vulnerable and marginalized groups, and then the development of legislation and the establishment of institutions that undertake the task of empowering [6].

\section{The second paragraph: Dimensions and indicators of women's empowerment}

Empowerment as a process involves a positive development and transition from one state (differentiation or inequality) to another (equality), 
as it mainly aims to "bring a positive change in power relations in society with the aim of eliminating the obstacles that limit women's choices and independence and have an impact negative impact on her life", provided that achieving this change will be through the presence of the woman as a positive active factor in the process of empowerment, and not only as a recipient [7], which makes this process include three basic data:

1. Resources: such as education, training and work as enabling elements, and their presence is necessary;

2. The human factor: in this case, the woman is the focus of the empowerment process, through which the selection and decision-making process takes place;

3. Results and achievements: which are represented in the political, economic and social gains made by women, and they are indicators on the basis of which it is possible to measure the extent of the success of the empowerment process [3].

Empowerment is a multi-dimensional process, and without it, women are not considered a fair participant in the development process, as knowledge of the factors and circumstances that cause women's dependence, whether at the macro or micro level in life, remains one of the most important pillars that enable critical review of women's experiences to observe and identify patterns of behavior leading to accreditation and support Dependency, so the cognitive dimension calls for knowing and understanding the need to make choices that may conflict with cultural and social expectations on the one hand, and on the other hand, the cognitive dimension seeks to understand male control over females, including the sexual aspect and physical abuse, and aims to understand and know the legal rights of women as a focus His attention and focus.

On the other hand, and since women can work to improve their individual and societal reality in which they live, the psychological dimension, given that this dimension is concerned with feelings and the extent to which women believe in the possibility of making a change in the course of their lives themselves, also confirms that women are brought up to submit to men and to allow Men make all decisions that affect them [8].

As empowerment is a process with data and elements, this process is integrated, with dimensions that cannot be separated from each other. Empowerment is economic as well as social/cultural empowerment, family/personal empowerment, legal empowerment, political empowerment, 
And psychological empowerment, and these dimensions are linked between them. The elements are at three levels: the family level, the community level, and the national level [8]. We can not only talk about the success of this process by achieving its indicators, which can be summarized in the following form:

Empowerment
- Change in
employment rates.
- Involvement of family
members in household
chores and childcare.
- The difference in
salaries and wages
between women and
men.
- Percentage of
ownership.
- Percentage of
expenditures on health
and education.
- The percentage of
opportunities available
to women to develop
their technical
capabilities, such as
technical services
provided by the
government or non-
governmental sources.

\section{Political empowerment}

- Percentage of women in local councils and decision-making centers.

- The proportion of women in the civil service.

- Percentage of women who registered to vote and be elected.

- The proportion of women entitled to vote of both sexes.

- Percentage of women in parliaments and notables.

\section{Social Empowerment}

- Number of women in civil society organizations.

- Comparing women in decision-making positions with the total number of individuals in formal and informal projects and departments.

- Freedom of decisionmaking with regard to reproduction.

- Freedom of movement internally and externally compared to men

Accordingly, the achievement of women's empowerment at all levels is linked to the achievement of its indicators, as reaching social empowerment is reflected in the extent to which there are procedures, measures and institutional interactions that are capable of achieving not only the social welfare of women and the eradication of poverty, but also the extent to which there are structures that help women build their capacities and engage effectively. and actual in civil society, their actual participation in decision-making, and the extent of their presence in decision-making positions. Achieving economic empowerment is mainly related to the percentage of women's presence in jobs and the availability of the appropriate environment to help women work, 
As well as the extent to which the state has adopted a policy of equal pay between men and women, thus reducing the gender gap and removing barriers that impede women's advancement, from discriminatory laws to unfair participation in bearing the burdens of home and family care [9].

\section{The second requirement: tracks of international and Arab efforts to empower women}

Gender justice has become an indicator of human development and good governance, and the international interest in social justice, especially the aspect related to the gender approach, has had a significant impact on Arab societies, as awareness has gradually increased in various Arab societies of the importance of women's participation in development. The need for the development process itself to revolve around women as a goal in itself, as well as a participant in the entire development process at all levels and fields [10], and because achieving gender justice is linked to the process of empowerment. Taken by some Arab countries to solve the problem of exclusion and marginalization and to download the principle of women's empowerment.

\section{Paragraph One: International efforts to endorse the principle of women's empowerment}

International law in the field of women's rights moved from viewing them as in need of special protection and preferential treatment, to the idea of demanding equality between men and women, complete equality on the basis of the law, and the protection of women in international human rights law moved to other issues, such as violence against women and trafficking in women. and their economic and sexual exploitation [11].

Equality in rights and duties between the sexes has been established since 1945, when states have adopted a basic principle of the United Nations Charter, which is "equality in rights between men and women" [12], as well as the universality of human rights without discrimination or differentiation between women and men [13]. A legal norm that is binding on all member states of the United Nations, and in the same regard the High Commissioner for Human Rights pledged to be an important factor in gender equality with her commitment to support gender equality in the Office of the High Commissioner for Human Rights and international forums [14]. 
A decent life for women and their liberation from discrimination, whether in jobs or in all other rights, or through the abolition of the slave trade regardless of color and origin [15].

The international conventions that protect the rights of the sexes and establish gender equality have continued. The provisions of the two international covenants of 1966 [16] affirm the right to equality between men and women in all fields and in some stipulated provisions stressing the obligation of states to ensure this equality. The Convention on Economic, Social and Cultural Rights: "The states parties to the present agreement undertake to ensure the equal rights of men and women to the enjoyment of all economic, social and cultural rights" [17].

The United Nations has made unremitting efforts to find special legal documents through which to address the existing case of discrimination against women, and the beginning was with the adoption by the United Nations of the first international document dealing exclusively with international women's rights and the right of implementation of the 19/12/19 Treaty. 1954, which stipulates that women have the right on equal terms with men to exercise their right to vote in elections and to hold public office and exercise all functions [18], and the General Assembly issued its resolution No. 2763 of Decree No. 22 of 1967 To eliminate the policy of gender discrimination. The General Assembly also declared 1975 the International Year of Women and issued Resolution No. (3010-D27 on December 18, 1975) [19].

Thus, international agreements worked to clarify and confirm the important role that women play in society at all levels and their right to enjoy all rights equally with men, and this was confirmed by the Convention on the Elimination of Discrimination against Women of 1967 and the Convention on the Elimination of All Forms of Discrimination against Women of 1979, which worked On collecting all forms of discrimination and all kinds of rights of women and men, and taking into account the status and capabilities of women in the service of society [20]. In addition to several agreements that concern the establishment of women's human rights [21].

The matter did not stop there, but went beyond it to the development of special organs for women in the United Nations. In July of the year 2010, the General Assembly established the United Nations Women, which is an entity concerned with gender equality and the empowerment of women. This body was established to speed up meeting the needs of women throughout the scientist. 
The United Nations General Assembly adopted the Convention on the Elimination of All Forms of Discrimination against Women in 1979 [22], through which it proceeded to endorse the principle of prohibition of discrimination against women, and to include the principle in the International Bill, and expressly stipulate it, as well as recognizing the need to establish national programs to end discrimination [23]. All signatory states to the Convention are obligated to work towards achieving equality between women and men in all political, economic, social and cultural fields (...), as well as working to empower women through the enactment of national legislation prohibiting discrimination, and taking temporary special measures to accelerate the achievement of equality. The truth between a man and a woman [24].

For its part, the International Labor Organization (ILO) works to support women's economic empowerment and gender equality as two main development goals, and given that women's empowerment will contribute to increasing economic growth and can affect poverty reduction [25]. The ILO also seeks to overcome the constraints that limit women's economic empowerment, by including the gender dimension in all programs and policies; And through women-specific interventions to address inequalities, and in this regard, the Organization issued a resolution on gender equality in access to decent work, adopted by the International Labor Conference at its 98th session in June 2009, which promotes gender equality in all strategic objectives The ILO's four, namely: Fundamental Principles and Rights at Work; employment; social protection; Social dialogue and the tripartite structure [25]. The push for the promotion of gender equality at work is characterized by several ILO conventions, as four conventions are of particular interest [26]. It also adopted international programs and curricula to empower women. We also find the Beijing Platform of Action for the year 1995, which included an agenda for empowering women with the aim of overcoming various obstacles.

\section{The second paragraph: Arab countries and the problem of downloading the principle of empowering women}

From a comparative anthropological and historical point of view, it turns out that the major transformations in the course of humanity, especially the path of wealth, energy and production, and the path of thought, theorizing and mental creativity, gave greater opportunities for men to be in the forefront, 
which led to the distribution of work and sources of economic and political power in favor of women. The transition from the matrilineal family system in origin to the patriarchal system was linked to the need to preserve the descendants of the tribe and clan and its honor by preventing women from leaving for work, internal marriage, preventing them from their right to inheritance, and thus obligating them to perform domestic and maternal work (the reproductive function), in exchange for the man responsible for Protection and provision of livelihood, and the path of thought and mental production had to reflect this division, and thus reduce the presence of women in the public field and limit their presence to the private field. The values and customs related to the role of women in society represent a major obstacle to improving the status of women and empowering them, as the culture of man's domination over women and the subordination of the latter, the preference of males over females, early marriage, and the belief that the place of women is the home [27].

The cultural framework in Arab societies, or what is called the collective mind, remains one of the most important factors and reasons that impede the downloading of the principle of women's empowerment and the strategies associated with it,

as the inherited mating with the acquired at various levels and returning it to produce the same cultural framework through social institutions, i.e. reproducing it for the same The values and norms that entrench inequality between men and women, and stereotyped images of each gender, lead either to the absence or weakness of the legislative and legal structure that would endorse the principle of women's empowerment, or to the absence of an actual and proper implementation of this structure at the level of policies and strategies, or to the rejection of this evidence altogether On the part of the components of society, including women, as the lack of weakness of political and societal will leads to the continuation of violence, exclusion, marginalization and inequality against women.

The second topic: the legal and constitutional dimensions of women's empowerment in the Arab world

There is no doubt that the establishment of a state of truth and law requires the adoption of actual equality between all segments of society and its groups, that equality that does justice to the less fortunate and the most vulnerable groups. 
Public policies that translate the will of the constitutional legislator, and thus the will of the people / nation on the ground, are the bet that guarantees the adoption of human rights, including the human rights of women, and the achievement of equality and social justice through mechanisms, the most important of which is empowerment.

The Arab countries have worked to endorse the principles of human rights as they are universally recognized in their national legislation, on top of which is the principle of equality and nondiscrimination between citizens, whether on the basis of sex, color, race or language (...), and some of them have also approved requirements that they saw as capable of advancing the status of citizens. Women and the reduction of the exclusion from which they have suffered for a long time, however, despite what is approved by the legal code and what is included in strategies and plans, the empowerment of women in the Arab world is still difficult to achieve in the required manner. Through it, we aim to achieve the principle of equality through empowerment processes (the first requirement), and we will also try to monitor some of the constraints and obstacles that prevent the actual empowerment of women (the second requirement).

The first paragraph: the constitutional and legal foundations that embody the principle of women's empowerment

The obligations within each country are based on the constitutional principles and legal rules contained in its constitution and national legislation. The constitutions of most Arab countries have included principles that establish the constitutionality of women's human rights. Some Arab legislations have tended to constitutionally recognize the principle of empowerment and emphasize the need to download it through national strategies and public policies. and sectoral. The UAE constitution has adopted some articles supporting the empowerment of women, as it guarantees them equal rights with men, and put them in an equal legal position with him, not in terms of opportunities for education and the pursuit of professions, or employment and holding high positions in the state, candidacy and election, and health care, as the constitution stipulates in Article 25 of Chapter Three states: "All individuals are equal before the law, and there is no discrimination among the citizens of the Union because of origin, domicile, religious belief, or social status" [28]. 
Personality and guarantees to protect citizens' security and equality, as Article 14 of the Constitution stipulates the basic components on which the Union is based, which are equality, social justice, security and tranquility, equal opportunities for all citizens, solidarity and compassion.

For its part, the Egyptian Constitution of 2014 included provisions that were considered a good opportunity to enhance the presence of women in the public scene, enhance their participation, especially political ones, and ensure their access to decision-making positions. Opportunities between all citizens, and the offense of discrimination of all kinds in Article 53, as well as incitement to hatred, and any discriminatory practice has become a crime that requires punishment. Accordingly, I must be obligated to review the laws that contain discriminatory texts, and work to amend them, and the same article stipulates the establishment of a commission to combat all forms of discrimination. Article 11 also stipulates the need for the state to take measures and measures to address the discrimination that women are subjected to regarding holding leadership positions and public positions and assuming positions in judicial bodies [29].

For its part, Morocco, after the 2011 constitutional review, adopted guarantees to protect human rights as they are universally recognized, with the prohibition of all forms of discrimination between individuals. It also stressed, through Chapter 6, the need to activate the principle of gender equality, while urging the state to strive towards achieving The principle of parity between men and women, which reflects a political will to advance the conditions of women and fortify them in various fields [30], based on a general principle that stipulates the necessity of empowering women legally, politically, economically and socially in order to achieve actual equality between women and men.

Morocco is also one of the few countries in the world that explicitly stipulates the principle of parity in the constitution, in addition to the principle of equal opportunities for both sexes, as Article 19 of the 2011 constitution stipulates that "...the state seeks to achieve the principle of parity between men and women, and it occurs for this purpose. An authority for parity and the fight against all forms of discrimination. This constitutional requirement translates the desire of the Moroccan legislator to work on empowering women and achieving real equality between them and men and granting women their right to participate alongside men in managing public 
affairs and achieving development. On the other hand, and in order to establish the principle of equality as well as the empowerment of women, the Moroccan constitution, in Chapter 31, obligates the state, public institutions and territorial communities to work on mobilizing all available means to facilitate the reasons for the equal benefit of female and male citizens from the right to access public jobs according to entitlement.

In an attempt to achieve harmony between the legislative and regulatory texts with the constitution, the principle of parity and equal opportunities has been included in the regulatory laws regulating the appointment procedure for senior positions in which appointments are discussed in the Government Council, which are requirements that support and empower women to reach decision-making positions. For example, but not limited to, the organizational law of the House of Councilors included the requirements of parity in the electoral regulations for the election of members of the House [31].

The second paragraph: Examples of Arab strategies to implement the principle of women's empowerment

Most governments in the Arab world have developed plans, strategies and created institutions charged with advancing the gender equality scheme. These institutions play an important role in developing policies, programs and tools that enable greater gender equality, whether in the public or private sectors.

[32]. Public and sectoral policies have also been adopted with the aim of integrating women and empowering them politically, economically, socially and culturally and increasing their participation in managing public affairs, as well as their presence in decision-making positions.

1. The National Strategy for Women Empowerment and Entrepreneurship in the United Arab Emirates

The United Arab Emirates launched a national project to empower women in 2005, which had very important results at all levels. Women in the UAE held high positions, and occupied approximately $66 \%$ of government positions and jobs in the country, including $3 \%$ in senior and related leadership positions. Decision making [33]. 
The National Strategy for Women's Empowerment 2015-2021, launched in 2015, also allowed the provision of a framework for the government and private sectors, as well as civil society institutions, to develop plans and work programs, which contribute to making the UAE among the most advanced countries in the field of women's empowerment and leadership. This national strategy included four basic priorities, namely maintaining the sustainability of the achievements of Emirati women, and preserving the social fabric and its cohesion through the integration of roles between men and women, to build a strong and cohesive society capable of keeping pace with emerging changes, as well as providing the ingredients for a decent, safe and well-being. Social foundations of high-quality foundations for women capable of developing the spirit of responsibility and leadership and enhancing their position [34].

According to the Human Development Indicators issued by the United Nations Development Program 2007-2008, the United Arab Emirates was able to rank 39 [35] in the field of women's empowerment, as women assumed ministerial and political positions through their entry into the Federal National Council, and their work in representing the state through Its embassies in the world in addition to entering the field of justice, and the field of the financial and banking sector, as women constituted $69 \%$ of the workforce and citizenship in this sector [36].

2. West Empowerment; The National Integrated Program for the Economic Empowerment of Women and Girls

Morocco is among the first countries that paid special attention to issues of combating violence against women with the participation of all actors, from government sectors, parliament, civil bodies and the media [37]. rights and duties and strive to achieve parity. These reforms began with the state's adoption of a reform approach for the benefit of women in 1998, in order to eliminate violence directed against them, considering its effects on various fields and institutions [38], and casting a shadow over women's contribution to the sustainable development that Morocco seeks, in addition to keeping pace with and coordinating with International commitments that Morocco has committed internationally.

After the constitutional review of 2011, Morocco established new concepts in order to achieve de facto equality between women and men, by approving several requirements that fall into this framework, 
Such as approving the principle of equal opportunities and downloading the principle of parity. A national plan for equality (Ikram 1 and Ikram 2) was developed, and work was done to download the national program for economic empowerment of women and girls by 2030 with the aim of strengthening women's economic integration and empowerment in the development field in line with constitutional requirements and sustainable development goals [39].

3. Tunisia: National Strategy for the Economic and Social Empowerment of Women and Girls in Rural Areas 2017-2020

The issue of women's empowerment in the Tunisian experience was linked to a strategy that focused on the state's investment in education and health, and its keenness to adopt social policies based on gender equality in a way that enabled women to benefit from them, develop their capabilities, and achieve equality.

The Tunisian experience highlights that the empowerment of women can be achieved through superior reforms that create the appropriate environment for the work of women's organizations for more empowerment and equality. On the other hand, the post-revolution political context allowed for women's political participation more, as the development in Tunisia is a cumulative development that reflects the link between economic, social, political and legal change in a way that reflects on a better situation for women and gives them the ability to mobilize and mobilize in order to change qualitative power relations prevalent in society [40].

The second requirement: the constraints of achieving women's empowerment in the Arab world

The international interest in empowering women has echoed in national trends, as many countries have developed national strategies and plans to work towards achieving gender equality, as well as working to empower women at various levels, but the gap still widens between what these strategies approve and what has been implemented on the reality is reflected in the reality of women [40]. 


\section{The first paragraph: the limitations of public policies directed at empowering women}

Public policies are the best way to implement constitutional and legal requirements on the ground, and these policies are considered an actual translation of the national strategies developed, and in the issues of women's empowerment, public policies seem to know limitations in translating the legislative and legal momentum, whether included in the constitutional texts or lower legislation, because despite the fact that despite National plans and strategies developed aimed at empowering women at the economic, political, social and cultural levels, but women still suffer from exclusion, marginalization and systematic violence in all its forms, and despite some progress in the issue of economic empowerment of women, some practices still undermine not only the achievement of Economic empowerment, but rather from women's access to their economic rights on an equal basis with men, for example, but not limited to, Arab women face gender-based obstacles in the workplace, where employment policy and employment practice are still based on the principle of discriminatory wages [41]. Also, despite the adoption of public policies in social fields,

such as improving the conditions of females in the field of literacy and higher education, and achieving more equality in the field of education, there are still obstacles facing women in areas such as technical education, and the improvement in Arab women's education levels did not contribute as required. diversifying its economic activity, increasing its participation in the labor market, or reducing the wage gap between it and men [42].

\section{The second paragraph: the dominance of inequality values in the sociocultural dimension}

Socially, the unequal division of family and family responsibilities between women and men is still considered one of the obstacles that limit the empowerment of women, as women are expected, to varying degrees, to take upon themselves the bulk of childcare and family responsibilities, which they do. A recent World Bank study found that women actually take full care of their children and, on average, do three-quarters of household tasks. On the other hand, the socially dominant patriarchal system further reduces the margin of women's empowerment. Because of the complex network of interpersonal relationships in which the man occupies the dominant position, women are given limited options at best or can be limited by the most influential man in society. 


\section{Conclusion:}

The Sustainable Development Goals and the empowerment of all women and girls cannot be achieved without ensuring equal rights to resources, or without ensuring equal access to human rights for all. Achieving a new social contract requires establishing non-violence-free work environments and safe public places as prerequisites for improving women's productivity, as well as addressing conscious/unconscious biases. It works as a technology to promote equal opportunities for both sexes on the ground, which contributes to providing opportunities for real participation of women in public life, and to the advancement of leadership positions through which they contribute to making decisions affecting their daily lives. It also seeks to advance and encourage the plans and programs of government agencies. To take measures and measures that give women greater opportunities to obtain their rights, and works to give a great impetus to the institutional efforts made to activate equality and ensure equal presence, presence and participation at the level of decision-making bodies for both men and women in a manner that guarantees parity.

Empowerment of women is largely related to the readiness of the legal framework and the consequences of its absence or weakness, because the constitutional text is not sufficient, and it is also linked to the readiness of institutional structures at their various social levels, despite the presence of a greater number of women in public positions today than any other In the past, more gender equality could not be achieved without strengthening policies and legislation that encourage women to take up leadership positions.

\section{References}

[1] Lakrini, I. (2013). The quota and its role in empowering women. Masalek Magazine, P. 49.

[2] Empowerment of women, European Institute for Gender Equality, eige.europa.eu.

[3] Gender and Dimensions of Women Empowerment in the Arab World, Publications of the Arab Women Organization, 2010 edition, p. 80

[4] Malhotra, A., Schuler, S., Boender, C. (2002). Measuring Women's Empowerment as a Variable in International Development, Gender and Development Group of the World 
Bank, P. 6.

[5] Rahman, A. (2013), "Women's Empowerment: Concept and Beyond", Global Journal of Human Social Science, Issue 6, Folder 13, P. 10,11.

[6] Bebha, I. (2012). Small and Medium Enterprises as a Tool for Women's Economic Empowerment in Algeria, Master's thesis, Kasdi Merbah University, P. 8.

[7] Ismail, H.G., A Future Vision for the Economic Empowerment of Egyptian Women in Cairo Governorate, Sixth Conference of the National Council for Women, Cairo March 28.

[8] Adly, H., (2018). Economic and Social Empowerment and its Impact on Women's Political Participation: International Experiences, Friedrich-Ebert-Stiftung Publications, P. 89.

[9] Kiwan, F., Challenges of Political Development and Gender Relationships, Gender and Dimensions of Women Empowerment, Arab Women Organization, P. 209.

[10] Al-Nimri, N.F., (2014). International and legal mechanisms for protecting women's rights in light of globalization, a thesis for obtaining a master's degree in public law, Faculty of Law - Middle East University, P. 36.

[11] U. N. United Nations charter (full text). United Nations. https://www.un.org/en/aboutus/un-charter/full-text

[12] Bachelet, M. (2021, March 8). Women's rights and gender section (WRGS). OHCHR. https://www.ohchr.org/EN/Issues/Women/WRGS/P.s/WRGSIndex.aspx

[13] Abdel-Ghanim, M. (1991). Women's Rights in Public International Law and Islamic Law, Dar Al-Nahda Al-Arabiya, Cairo, first edition, P.. 6.

[14] Human Rights, (n.d.). International Covenant on Economic, Social and Cultural Rights. https://www.ohchr.org/en/professionalinterest/p.s/cescr.aspx

[15] Noureddine, K. (2015-2016). Women's Rights and Protection in International Human Rights Law, memorandum for obtaining a master's degree in international law and international relations, Tahar Moulay University - Faculty of Law and Political Sciences - 
Saida - Algeria, p. 18.

[16] Ibn Rajab, H. (2012). Women in Private Life and Political Charters, "Arab Women in Public and Political Life", Publications of the Arab Organization for Administrative Development, p. 125.

[17] Al-Ahmad, W. (2001). Protecting Women's Rights in the Light of Peace and International Agreements, Al-Halabi Human Rights Publications, Beirut, first edition, p. 82.

[18] Noureddine, K. (2015-2016). Women's Rights and Protection in International Human Rights Law, ibid., p. 20.

[19] Convention on Conflict of National Laws Relating to Marriage, Divorce, Separation and Guardianship of Minors, 1912.

[20] Convention on the Elimination of All Forms of Discrimination against Women, pursuant to United Nations General Assembly Resolution 34/180 of December 18, 1979.

[21] See a group of articles that stress the need to include in national laws to protect women "Articles 1 to 7".

[22] Article 3 of the Convention on the Elimination of All Forms of Discrimination against Women International Labor Organization, 12th African Regional Meeting Johannesburg, South Africa, 11-14 October 2011Document: AF

[23] Chiefly the Equal Remuneration Convention of 1951 No. 100; the Discrimination in Employment and Occupation Convention of 1958 No. 111; Also, Workers with Family Responsibilities Convention No. 156 of 1981; Maternity Protection Convention 2000 No. 183.

[24] Muhammad, D.R. The Reality of Egyptian Women and their Participatory Role in the Development Process, 34th Annual Conference on Population and Development Issues, Demographic Center, Cairo.

[25] Ezzat, M. (2018). Women in Decision-Making Positions in State Institutions and Civil Society Organizations, Friedrich Ebert Foundation, p. 28. 
[26] Belmaleh, S. (2013). Women's Rights and the Democratic Issue in Islamic Countries at the Present, Masalek magazine under the title "Women in the Constitution from the demand for inclusion to the right to download" double issue, p. 18

[27] Fatima Al-Zahra Baba Ahmed: The principle of parity

[28] Women's Economic Empowerment Forum in the Middle East and North Africa, OECD Initiative, October 2017.

[29] Abdel Hamid, A. (2016). Emirati women making qualitative gains and achievements in various fields, www.Alkhaleej.Ae/Alkhaleej/P./4c6dd855-6ebd-42fa-Bd7eF7148b1fd031/02/2016.

[30] The official portal of the UAE government https://u.ae/ar-ae/information-andservices/social-affairs/women

[31] Karkari Company, (2007). United Nations Development Program Human Development Report 2007/2008, Fighting Climate Change: Human Solidarity in a Divided World, p. 217.

[32] Al-Derby, A. (2011). Obligations arising from international conventions, human rights, a comparative study, the National Center for Legal Publications, p. 446.

[33] Governmental Plan for Equality "Honor on the Horizon of Equality" - 2016-2020, Publications of the Ministry of Solidarity, Women, Family and Social Development, 2013, p. 25.

[34] Spring of Dignity: Memorandum for a Law Eliminating Violence against Women, January 2014, New Knowledge Press - Rabat, p. 4.

[35] The official website of the Ministry of Solidarity, Social Development, Equality and the Family, https://social.gov.ma/

[36] Adly, H. (2018). Women's Political Participation, Friedrich Ebert Foundation, Egypt Office, also contributed to the preparation: Mona Ezzat, Ahmed Fawzy, Reham Bahy, Marwa Nazir. 
Academic Journal of Research and Scientific Publishing | Vol 3 | Issue 35

[37] International Labor Organization: Twelfth African Regional Meeting Johannesburg, South Africa, 11-14 October 2011 (Document: AF)

[38] Al-Shamsi, F., Aly, H. Y., (2010). Chapter Five: Globalization and Women's Status in the Arab World: Blessing or Curse?

[39] Korany, B., Sholkamy, H., Morsy, M., Women in the Concept and Issues of Human Security Arab and International Perspectives-Proceedings of the Second Conference of the Arab Women Organization.

Copyright $(2022$ Dr. Mohammad Hadie Al Najdawi, AJRSP. This is an Open-Access Article Distributed under the Terms of the Creative Commons Attribution License (CC BY NC) Doi: https://doi.org/10.52132/Ajrsp.e.2022.35.1 